\title{
ANALISIS LAJU KONDENSASI AKIBAT PENGARUH KECEPATAN UDARA TERHADAP KARAKTERISTIK PERPINDAHAN PANAS PADA OVEN PENGERING PATI SAGU KAPASITAS
}

\author{
Nicolas Titahelu ${ }^{1}$, Samy J. Litiloly ${ }^{2}$ \\ E-mail: ${ }^{1}$ titahelun@gmail.com, ${ }^{2}$ samyjunusl@yahoo.com \\ ${ }^{1,2}$ Jurusan Teknik Mesin, Fakultas Teknik Universitas Pattimura, Kampus Poka-Ambon, 97233, Indonesia
}

\begin{abstract}
ABSTRAK
Analisis laju kondensasi akibat pengaruh kecepatan udara (V) terhadap karakteristik perpindahan panas oven pengering pati sagu telah diteliti dengan perpindahan panas konveksi paksa dan diaplikasikan untuk mendesain oven pengering pati sagu guna menjawab kebutuhan masyarakat yang selama ini menggunakan cara pengeringan tradisional. Model uji dimodifikasi dengan memberikan saluran udara masuk dan keluar agar bilangan Nusselt meningkat dengan masukan panas $\left(\mathrm{Q}^{*}\right)=5.400 \mathrm{~kJ} / \mathrm{hr}$ konstan. Penelitian eksperimen dilakukan dengan variasi kecepatan udara $(\mathrm{V})=0.7 \mathrm{~s} / \mathrm{d} 1.0$ $\mathrm{m} / \mathrm{s}$, untuk mengamati karakteristik perpindahan panas dan laju kondensasi. Karakterik perpindahan panas meningkat seiring dengan membesarnya kecepatan udara. Semakin besar kecepatan udara untuk $(\mathrm{V})<0.9 \mathrm{~m} / \mathrm{s}$, maka karakteristik perpindahan panas konveksi dan laju kondensasi semakin meningkar dengan gradient kenaikan besar, sedangkan untuk kecepatan udara $(\mathrm{V})>0.9 \mathrm{~m} / \mathrm{s}$ karakteristik perpindahan panas dan laju kondensasi meningkat pula dengan gradient kenaikan kecil. Karakteristik perpindahan panas yakni bilangan Prandt (Pr) meningkat dari 0.6969 hingga 0.6974 atau meningkat sebesar $0.08 \%$, bilangan Reynold (Re) meningkat dari 233667.092 hingga 34216.484 atau meningkat sebsar $6.83 \%$, bilangan Nusselt $(\mathrm{Nu})$ maningkat dari 762.576 hingga 1084.454 atau meningkat sebesar 29.68\%, koefisien konveksi (h) meningkat dari $102.718 \mathrm{~kJ} / \mathrm{jam} . \mathrm{m}^{2} . \mathrm{K}$ hingga $124 \mathrm{~kJ} / \mathrm{jam} . \mathrm{m}^{2} . \mathrm{K}$ atau meningkat sebesar $17.16 \%$, laju perpindahan panas konveksi (qk) meingkat dari $12542.551 \mathrm{~kJ} / \mathrm{jam}$ hingga $15395.773 \mathrm{~kJ} / \mathrm{jam}$ atau meningkat sebesar $18.53 \%$. Laju kondensasi meningkat dari $0.152 \mathrm{~kg} / \mathrm{hr}-\mathrm{m}$ hingga $0.171 \mathrm{~kg} / \mathrm{hr}-\mathrm{m}$ atau meningkat sebesar $11.11 \%$.
\end{abstract}

Kata kunci : laju kondensasi, kecepatan udara, pati sagu, bilangan Nusselt, konveksi..

\section{PENDAHULUAN}

Sagu (Metroxylon $s p$ ) merupakan salah satu tanaman penghasil karbonhidrat yang cukup potensial di Indonesia, dapat dimanfaatkan dalam upaya mengoptimalkan program diversifikasi pangan non-beras. Lebih dari 50\% atau sekitar 1,1 juta ha diantaranya ada di Indonesia (Djoko Susato et al., 1987 dalam Dirjen Bina Produksi Perkebunan Deptan RI, 2004). Pati sagu dapat dimanfaatkan sebagai bahan baku industri pangan dan non-pangan, serta pati sagu dimanfaatkan dalam bentuk pati teroksidasi maupun pati terfosforilasi. Pemanfaatan pati sagu teroksidasi dalam berbagai industri diantaranya; industri kertas, dan industri tekstil, sedangkan pati sagu terfosforilasi dimanfaatkan dalam industri pangan, kertas, adhesive, tekstil, obat-obatan dan detergent (Widaningrum at al, 2005). Seiring perkembangan teknologi pati sagu juga dimanfaatkan sebagai bahan baku pembuatan plastik biodegrabel (Rindengan at al, 2003).

Umumnya teknologi pengolahan sagu menjadi pati sagu, di Indonesia masih dilakukan dengan cara tradisional termasuk di Maluku.
Proses pengolahan sagu meliputi; penebangan, ekstraksi empulur (penghancuran empulur), pelarutan pati, pemisahan pati sagu dan proses pengeringan. Biasanya pati sagu dikemas dalam tumang masih basah, maka penyimpanan hanya dapat dilakukan dalam beberapa hari, sehingga cendawan atau mikroba lainnya akan tumbuh yang menyebabkan tepung sagu berbau asam. Mutu pati sagu menurut Standar Nasional Indonesia (SNI) 01-3729-1995, salah satunya adalah kadar air maksimum 13\%.

Untuk mencapai kadar air yang diisyaratkan oleh SNI, maka melalui cara tradisional pati sagu dikeringkan dengan bantuan sinar matahari. Menurut Yuliasih (2009) proses pengeringan ini juga mempunyai kelebihan karena proses kerjanya mudah dan tidak menyulitkan, tetapi kelemahannya sangat tergantung pada cuaca atau musim.

Berbagai penelitian terdahulu yang dilakukan oleh Purwani et al. (2006), pati sagu yang berkualitas baik dapat diperoleh melalui perlakuan panas basah (HMT/ Heat Moisture Treatment) yang mana membuat pati sagu menjadi lebih 
stabil saat pemasakan. Perlakuan HMT merupakan salah satu modifikasi pati sagu secara fisik dengan menggunakan kombinasi kelembaban dan temperatur. Selain itu Jading, et al. (2009) melakukan penelitian dengan alat pengering croos flow fluidized bed bertenaga surya dan biomassa mempunyai prinsip kerja sebagai berikut; udara pengering yang digunakan berasal dari kolektor surya dan pembakaran biomassa. Proses kerja dari alat ini adalah bed yang berada di dalam ruang pengering berfungsi untuk memutar pati sagu hingga memisahkan pati yang sudah kering, sedangkan serat-serat yang menempel pada pati sagu dibuang melalui ruang udara yang sudah di setel untuk membuang hasil sisa pembakaran yang berada pada tabung di dalam ruang pemanas.

Pemasalahan yang terjadi dalam proses pengeringan pati sagu sangat tergatung pada cuaca yang sangat tidak menentu baik pada musim barat maupun musim timur, sehingga waktu pengeringan pati sagu menjadi panjang. Dari permasalahan di atas, maka penelitian didesain sebuah oven pengering pelat datar yang memanfaatkan energi panas dari boiler yang disirkulasikan dalam pipa-pipa kondensor dengan memanfaatkan fan atau kipas angin untuk menghembuskan energi panas kedalam ruang pengering untuk mengeringkan pati sagu. Pati sagu dihamparkan diatas pelat datar yang direkayasa dengan memanfaatkan timbangan guna mengetahui massa pati sagu dan kadar air seperti yang disyaratkan oleh SNI yakni 13\%.

Proses pengeringan pati sagu yang terjadi dalam ruang pengering berlangsung dengan mekanisme perpindahan panas konveksi paksa, dimana ada pengaruh gaya luar terhadap proses perpindahan panas dari pati sagu. Kecepatan udara merupakan salah satu parameter yang sangat mempengaruhi bilangan Reynold (Re) dimana kecepatan udara berbanding lurus dengan bilangan Reynold. Bilangan Nusselt merupakan salah satu parameter penentu dari karakteristik perpindahan panas konveksi paksa, dimana bilangan Nusslelt merupakan fungsi dari bilangan Reynold dan bilangan Prandlt. Semakin tinggi bilangan Nusselt berarti semakin baik proses perpindahan panas konveksi paksa yang terjadi dari pati sagu dalam ruang pengering. Dengan meningkatnya kecepatan udara mengindikasikan bahwa proses pengeringan pati sagu akan semakin cepat. Menurut Farel et al. (2012) menyatakan bahwa pengeringan bertujuan memperpanjang umur simpan dengan cara mengurangi kadar air untuk mencegah tidak ditumbuhi oleh mikroorganisme pembusuk, dimana dalam proses pengeringan dilakukan pengaturan terhadap suhu, kelembaban dan aliran udara. Makalah ini bertujuan untuk menganalisis laju kondensasi akibat kecepatan udara terhadap karakteriktik perpindahan panas konveksi oven pengering pati sagu.

\section{KAJIAN TEORI DAN METODE}

\section{Karakteristik Perpindahan Panas Konveksi}

Menurut Bergman et al. (2011), menyatakan bahwa bilangan Reynold (Re) merupakan perbandingan gaya viskous dan gaya inersia, dinyatakan sebagai

$$
R e_{L}=\frac{V \cdot L}{v}
$$

dimana: $\mathrm{V}=$ kecepatan udara $(\mathrm{m} / \mathrm{s}), \mathrm{L}=$ panjang karakteristik $(\mathrm{m}), v=$ viskositas kinematis $\left(\mathrm{m}^{2} / \mathrm{s}\right)$.

Menurut Kays et al. (1993), untuk mencari bilangan Nusselt $(\mathrm{Nu})$ memiliki banyak persamaan yang dapat digunakan untuk aliran di luar silinder, yakni persamaan Churchill dan Berstein yang merupakan persamaan komprehensif tunggal mencakup bilangn Reynold (Re) dan bilangan Prandtl (Pr) untuk berbagai data, dinyatakan dalam persamaan

$$
N u=0.3+\frac{\left(0.62 R_{e l^{\frac{1}{2}} P r^{\frac{1}{3}}}\right)}{\left(1+\left(\frac{0.4}{P r}\right)^{\frac{2}{3}}\right)^{\frac{1}{4}}} \times\left(1+\left(\frac{R_{e l}}{282,000}\right)^{5 / 8}\right)^{4 / 5}
$$

Untuk $\left[\operatorname{Re}_{l} \operatorname{Pr}\right]>0.2$

Menurut Naylor et al. (1999), untuk menghitung koefisien konveksi digunakan persamaan

$$
h=\frac{k}{L} N u
$$

dimana $\mathrm{K}=$ konduktivtas termal $(\mathrm{W} / \mathrm{m} . \mathrm{K})$, $\mathrm{L}=$ panjang karakteristik $(\mathrm{m}), \mathrm{Nu}=$ bilangan Nusselt.

Menurut Cengel (1998), konveksi adalah proses perpindahan panas yang terjadi bila ada gradient temperatur antara permukaan benda padat dengan fluida yang bergerak melintasi permukaan tersebut. Perpindahan panas konveksi dinyatakan dengan hukum Newton pendinginan

$$
q_{k}=\bar{h} \cdot A\left(T_{s}-T_{\infty}\right)
$$

dimana $\mathrm{q}_{\mathrm{k}}=$ laju perpindahan panas konveksi $(\mathrm{kJ} / \mathrm{jam}), \quad \bar{h}=$ koefisien perpindahan panas 
konveksi rerata $\left(\mathrm{kJ} / \mathrm{jam} . \mathrm{m}^{2} . \mathrm{K}\right), T_{s}=$ temperatur permukaan $(\mathrm{K}), T_{\infty}=$ temperatur fluida aliran bebas $(\mathrm{K})$.

\section{Laju Kondensasi}

Menurut Widyawan et al. 2013, menyatakan bahwa laju kondensasi steam akibat kehilangan panas sepanjang aliran di pipa-pipa kondensor merupakan perbandingan antara kehilangan panas yang timbul dari pipa ke lingkungan terhadap kehilangan panas dari steam saat terjadi kondensasi.

Kehilangan panas sepanjang aliran di pipapipa kondensor ke lingkungan menggunakan persamaan:

$$
q_{p}=\frac{\pi\left(T_{s}-T_{a}\right)}{\frac{2.3}{2 K_{c}} \log \frac{D_{O}}{D_{i}}+\frac{1}{h_{a} D_{i}}}
$$

dimana $\mathrm{T}_{\mathrm{a}}=$ temperatur sekeliling $(\mathrm{K})$ $\mathrm{T}_{\mathrm{s}}=$ temperatur pipa-pipa kondensor $(\mathrm{K})$, $\mathrm{D}_{\mathrm{o}}=$ diameter luar pipa kondensor (m), $\mathrm{D}_{\mathrm{i}}=$ diameter dalam pipa kondensor $(\mathrm{m})$, $\mathrm{K}_{\mathrm{c}}=$ konduktivitas termal pipa kondensor (kJ/jam.m.K).

Kehilangan panas dari steam saat terjadi kondensasi dinyatakan dalam persamaan

$$
q_{s}=h_{g}-h_{f}
$$

Dimana $\mathrm{h}_{\mathrm{g}}=$ entalpi superheated steam $(\mathrm{kg} / \mathrm{kJ})$, $\mathrm{h}_{\mathrm{f}}=$ entalpi saturated steam $(\mathrm{kg} / \mathrm{kJ})$.

Laju kondensasi dinyatakan dengan persamaan

$$
q_{c}=q_{p} / q_{s}
$$

dimana $\mathrm{q}_{\mathrm{c}}=$ laju kondensasi ( $\left.\mathrm{kg} / \mathrm{hr} . \mathrm{m}\right)$.

\section{Peralatan Penelitian}

Adapun variabel bebas penelitian ini adalah kecepatan yang divariasikan dari $0.7 \mathrm{~m} / \mathrm{s}$ hingga $1.0 \mathrm{~m} / \mathrm{s}$ dengan masukan panas $5.400 \mathrm{~kJ} / \mathrm{jam}$ konstan, sedangkan variabel terikat yakni karakteristik perpindahan panas konveksi yakni; $\mathrm{Pr}, \mathrm{Re}, \mathrm{Nu}, \mathrm{h}, \mathrm{q}_{\mathrm{k}}$ dan laju kondensasi yakni; $\mathrm{q}_{\mathrm{p}}, \mathrm{q}_{\mathrm{s}}$, $\mathrm{q}_{\mathrm{c}}$. Instalasi penelitian eksperimen disajikan dalam gambar 1 .

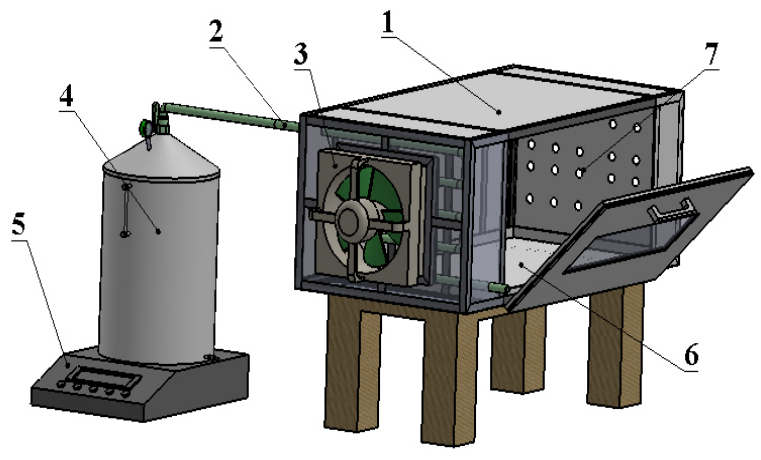

Gambar 1. Peralatan uji

Keterangan gambar : (1). Ruang pengering, (2). Pipa kondensor, (3). Kipas, (4). Ketel, (5). Kompor listrik, (6). Kolektor pelat datar, (7). Saluran udara keluar.

Prinsip kerja peralatan uji sebagai berikut:

- Menyiapkan model uji sesuai dengan gambar 1

- Pati sagu basah ditimbang massa awal sebesar $5 \mathrm{~kg}$ dan digelar di atas pelat datar dalam oven pengering

- Memasang alat ukur temperatur yakni termokopel tipe $\mathrm{K}$ dan dihubungkan dengan termokopel digital untuk mengukur temperatur. Mengatur putaran fan sebesar 0.7 $\mathrm{m} / \mathrm{s}$ dan kecepatan udara diukur dengan anemometer.

- Menghidupkan kompor listrik untuk memanaskan air dalam ketel dengan masukan panas sebesar $5.400 \mathrm{~kJ} / \mathrm{hr}$ konstan.

- Mengamati tekanan, temperatur air dalam ketel serta kecepatan udara, jika temperatur air telah mendekati titik didih, maka dibuka keran pipa kondensor sehingga steam dapat mengalir dari ketel ke pipa-pipa kondensor.

- Melakukan pencatatan data penelitian selang 15 menit berupa data temperatur pipa kondensor, temperatur udara masuk dan keluar serta temperatur kamar, tekanan ketel, kecepatan udara, massa pati sagu dan waktu pengeringan.

- Jika massa pati sagu akhir telah mencapai 3,3 $\mathrm{kg}$, maka pengambilan data selesai. Mematikan dan mendinginkan oven pengering.

- Selanjutnya tahapan penelitian diulangi dengan mengatur kecepatan udara untuk 0.8 , 0.9 dan $1,0 \mathrm{~m} / \mathrm{s}$. 


\section{HASIL DAN PEMBAHASAN}

\section{Hasil Penelitian}

Penelitian secara eksperimen dilakukan dengan memvariasikan kecepatan udara $(\mathrm{V})=0.7$ $\mathrm{s} / \mathrm{d} 1.0 \mathrm{~m} / \mathrm{s}$, diperoleh data disajikan dalam tabel 1 .

Tabel 1. Data Penelitian

\begin{tabular}{|l|r|r|r|r|}
\hline \multirow{2}{*}{ Parameter } & \multicolumn{5}{|c|}{ Kecepatan udara (m/s) } \\
\cline { 2 - 5 } & \multicolumn{1}{|c|}{0.7} & \multicolumn{1}{|c|}{0.8} & \multicolumn{1}{c|}{0.9} & \multicolumn{1}{c|}{1.0} \\
\hline $\mathrm{Q}^{*}(\mathrm{~kJ} / \mathrm{jam})$ & 5.400 & 5.400 & 5.400 & 5.400 \\
\hline $\mathrm{P}(\mathrm{bar})$ & 0.9 & 0.9 & 0.9 & 0.9 \\
\hline $\mathrm{T}_{\mathrm{t}}(\mathrm{K})$ & 362,5 & 360.6 & 359.9 & 359.1 \\
\hline $\mathrm{T}_{\mathrm{k}}(\mathrm{K})$ & 373.15 & 373.15 & 373.15 & 373.15 \\
\hline $\mathrm{T}_{\mathrm{c}, \mathrm{i}}(\mathrm{K})$ & 313.25 & 312.15 & 310.15 & 309.95 \\
\hline $\mathrm{T}_{\mathrm{c}, \mathrm{O}}(\mathrm{K})$ & 309.65 & 308.6 & 307.15 & 306.65 \\
\hline $\mathrm{T}_{\mathrm{h}, \mathrm{i}}(\mathrm{K})$ & 373.15 & 373.15 & 373.15 & 373.15 \\
\hline $\mathrm{T}_{\mathrm{h}, \mathrm{o}}(\mathrm{K})$ & 370.15 & 370.15 & 370.15 & 370.15 \\
\hline $\mathrm{T}_{\mathrm{p}}(\mathrm{K})$ & 308.55 & 307.25 & 304.75 & 304.44 \\
\hline $\mathrm{t}(\mathrm{jam})$ & 24 & 21 & 19 & 17 \\
\hline $\mathrm{M} 1(\mathrm{~kg})$ & 5 & 5 & 5 & 5 \\
\hline $\mathrm{M} 2(\mathrm{~kg})$ & 3.4 & 3.4 & 3.4 & 3.4 \\
\hline KAAw $(\%)$ & 40 & 40 & 40 & 40 \\
\hline KAAk (\%) & 15 & 15 & 15 & 15 \\
\hline
\end{tabular}

Sumber: Lab. Perpindahan panas, 2017

\section{Pembahasan}

\subsection{Karakteristik Perpindahan Panas}

\section{- Bilangan Prandtl (Pr)}

Hasil eksperimen dengan memvariasikan kecepatan udara $(\mathrm{V})=0,7-1,0 \mathrm{~m} / \mathrm{s}$ pada masukan panas $\left(\mathrm{Q}^{*}\right)=5.400 \mathrm{~kJ} / \mathrm{jam}$ konstan, memperlihatkan bahwa semakin besar kecepatan udara (V), maka bilangan Prandl (Pr) semakin meningkat disajikan pada gambar 2 .

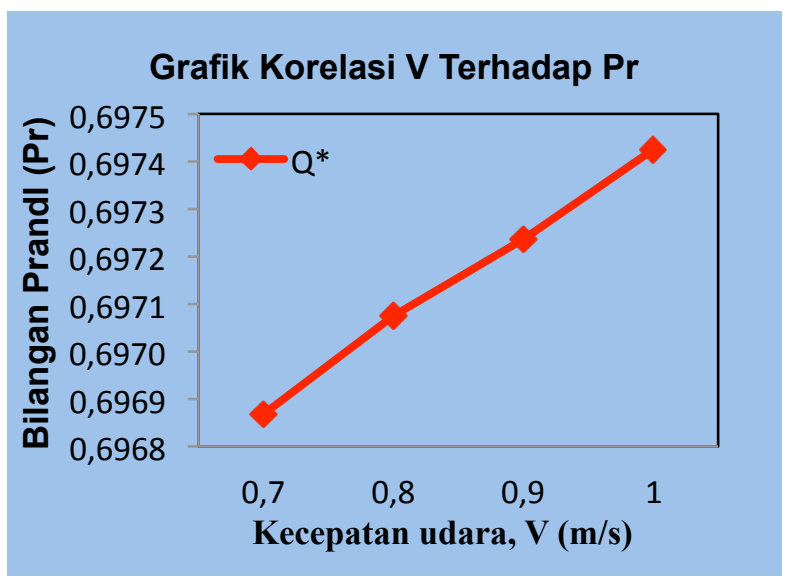

Gambar 2. Korelasi kecepatan udara (V) terhadap bilangan Prandl (Pr)

Gambar 2 memperlihatkan bahwa bilangan Prandl (Pr) minimal terhadap pada kecepatan udara 0.7 $\mathrm{m} / \mathrm{s}$ sedangkan bilangan Prandl maksimal pada kecepatan udara $1.0 \mathrm{~m} / \mathrm{s}$. Semakin besar kecepatan udara $(\mathrm{V})<0.9$ bilangan Prandl meningkat dengan gradian kenaikan kecil, dan untuk kecepatan udara $(\mathrm{V})>0.9$ bilangan Prandl meningkat pula dengan gradien kenaikan yang besar.

\section{- Bilangan Reynold (Re)}

Hasil eksperimen dengan memvariasikan kecepatan udara $(\mathrm{V})=0,7-1,0 \mathrm{~m} / \mathrm{s}$ pada masukan panas $\left(\mathrm{Q}^{*}\right)=5.400 \mathrm{~kJ} / \mathrm{jam}$ konstan, memperlihatkan bahwa semakin besar kecepatan udara (V), maka bilangan Reynold (Re) semakin meningkat disajikan pada gambar 3 .

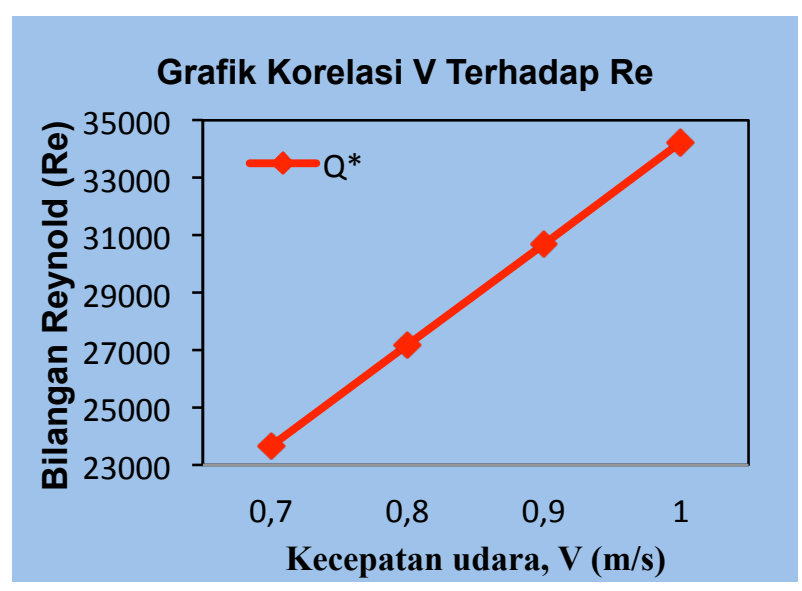

Gambar 3. Korelasi kecepatan udara (V) terhadap bilangan Reynold (Re)

Gambar 3 memperlihatkan bahwa bilangan Reynold (Re) minimal terhadap pada kecepatan udara $0.7 \mathrm{~m} / \mathrm{s}$ sedangkan bilangan Reynold (Re) maksimal pada kecepatan udara $1.0 \mathrm{~m} / \mathrm{s}$. Semakin besar kecepatan udara $(\mathrm{V})<0.9$ bilangan Reynold (Re) meningkat dengan gradian kenaikan kecil, tetapi kecepatan udara $(\mathrm{V})>0.9$ bilangan Reynold (Re) meningkat pula dengan gradien kenaikan yang besar

\section{- Bilangan Nusselt (Nu)}

Hasil eksperimen dengan memvariasikan kecepatan udara $(\mathrm{V})=0,7-1,0 \mathrm{~m} / \mathrm{s}$ pada masukan panas $\left(\mathrm{Q}^{*}\right)=5.400 \mathrm{~kJ} / \mathrm{jam}$ konstan, memperlihatkan bahwa semakin besar kecepatan udara (V), maka bilangan Nusselt $(\mathrm{Nu})$ semakin meningkat disajikan pada gambar 4 . 


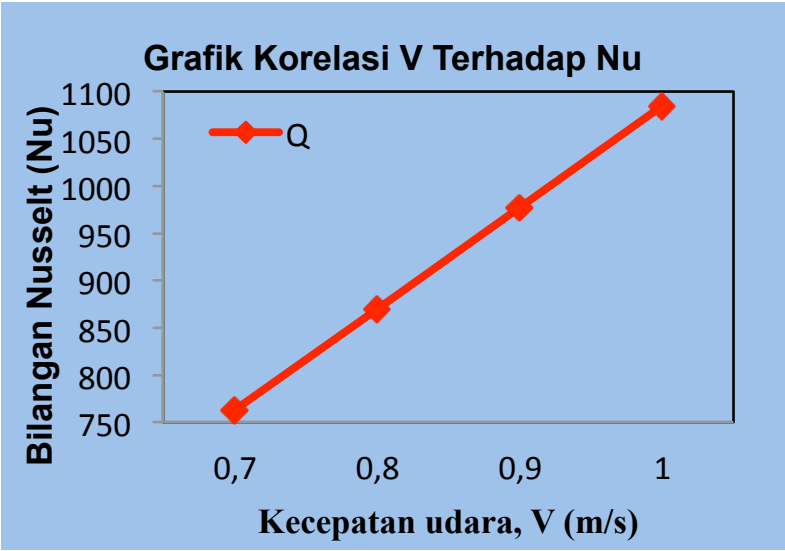

Gambar 4. Korelasi kecepatan udara (V) terhadap bilangan Nusselt $(\mathrm{Nu})$

Gambar 4 memperlihatkan bahwa bilangan Nusselt $(\mathrm{Nu})$ minimal terhadap pada kecepatan udara $0.7 \mathrm{~m} / \mathrm{s}$ sedangkan bilangan Nusselt $(\mathrm{Nu})$ maksimal pada kecepatan udara $1.0 \mathrm{~m} / \mathrm{s}$. Semakin besar kecepatan udara $(\mathrm{V})<0.9$ bilangan Nusselt $(\mathrm{Nu})$ meningkat dengan gradian kenaikan kecil, tetapi kecepatan udara $(\mathrm{V})>0.9$ bilangan Nusselt $(\mathrm{Nu})$ meningkat pula dengan gradien kenaikan yang besar.

\section{- Koefisien Konveksi (h)}

Hasil eksperimen dengan memvariasikan kecepatan udara $(\mathrm{V})=0,7-1,0 \mathrm{~m} / \mathrm{s}$ pada masukan panas $\left(\mathrm{Q}^{*}\right)=4.500 \mathrm{~kJ} / \mathrm{jam}$ konstan, memperlihatkan bahwa semakin besar kecepatan udara (V), maka bilangan koefisien konveksi (h) semakin meningkat disajikan pada gambar 5 .

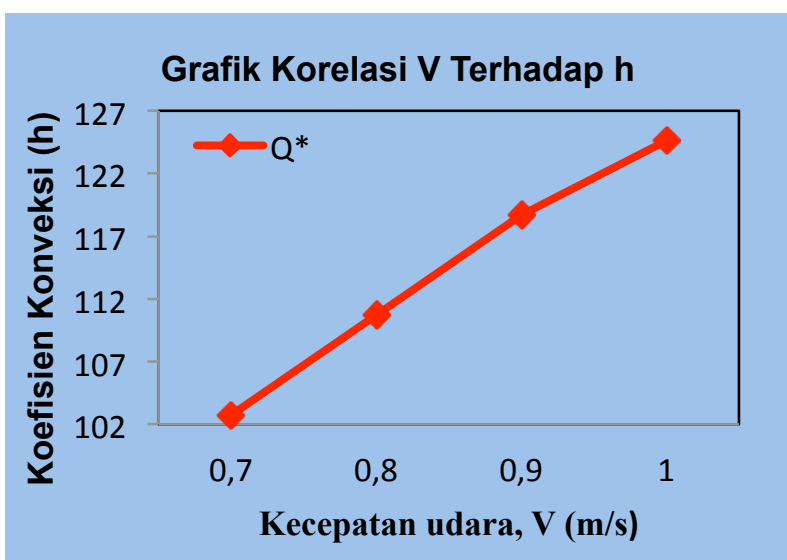

Gambar 5. Korelasi kecepatan udara (V) terhadap koefisien konveksi (h)

Gambar 5 memperlihatkan bahwa koefisien konveksi (h) minimal terhadap pada kecepatan udara $0.7 \mathrm{~m} / \mathrm{s}$ sedangkan koefisien konveksi (h) maksimal pada kecepatan udara $1.0 \mathrm{~m} / \mathrm{s}$. Semakin besar kecepatan udara (V) $<0.9$ koefisien konveksi (h) meningkat dengan gradian kenaikan kecil, tetapi kecepatan udara $(\mathrm{V})>0.9$ koefisien konveksi (h) meningkat pula dengan gradien kenaikan yang besar.

\section{- Laju Perpindahan Panas Konveksi $\left(q_{k}\right)$}

Hasil eksperimen dengan memvariasikan kecepatan udara $(\mathrm{V})=0,7-1,0 \mathrm{~m} / \mathrm{s}$ pada masukan panas $\left(\mathrm{Q}^{*}\right)=5.400 \mathrm{~kJ} / \mathrm{jam}$ konstan, memperlihatkan bahwa semakin besar kecepatan udara $(\mathrm{V})$, maka laju perpindahan panas konveksi $\left(\mathrm{q}_{\mathrm{k}}\right)$ semakin meningkat disajikan pada gambar 6 . Gambar 6 memperlihatkan bahwa laju perpindahan panas konveksi $\left(\mathrm{q}_{\mathrm{k}}\right)$ minimal terhadap pada kecepatan udara $0.7 \mathrm{~m} / \mathrm{s}$ sedangkan laju perpindahan panas konveksi $\left(\mathrm{q}_{\mathrm{k}}\right)$ maksimal pada kecepatan udara $1.0 \mathrm{~m} / \mathrm{s}$. Semakin besar kecepatan udara $(\mathrm{V})<0.9$ laju perpindahan panas konveksi $\left(\mathrm{q}_{\mathrm{k}}\right)$ meningkat dengan gradian kenaikan kecil, tetapi kecepatan udara $(\mathrm{V})>0.9$ laju perpindahan panas konveksi $\left(\mathrm{q}_{\mathrm{k}}\right)$ meningkat pula dengan gradien kenaikan yang besar.

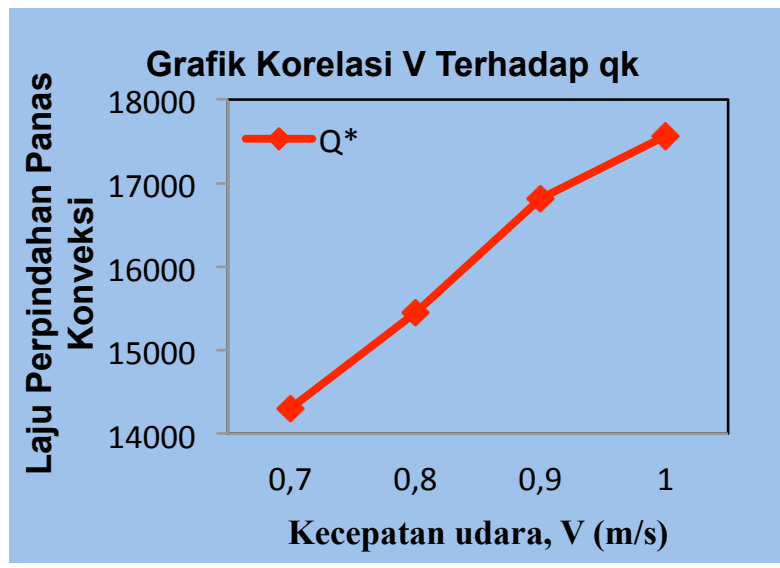

Gambar 6. Korelasi kecepatan udara (V) terhadap laju perpindahan panas konveksi $\left(q_{k}\right)$

\subsection{Laju Kondensasi}

\section{- Kehilangan Panas Pipa-pipa Kondensor $\left(q_{p}\right)$}

Hasil eksperimen dengan memvariasikan kecepatan udara $(\mathrm{V})=0,7-1,0 \mathrm{~m} / \mathrm{s}$ pada masukan panas $\left(\mathrm{Q}^{*}\right)=5.400 \mathrm{~kJ} / \mathrm{jam}$ konstan, memperlihatkan bahwa semakin besar kecepatan udara $(\mathrm{V})$, maka kehilangan panas pipa kondensor $\left(\mathrm{q}_{\mathrm{p}}\right)$ semakin meningkat disajikan pada gambar 7 .

Gambar 7 memperlihatkan bahwa kehilangan panas pipa kondensor $\left(\mathrm{q}_{\mathrm{p}}\right)$ minimal terhadap pada kecepatan udara $0.7 \mathrm{~m} / \mathrm{s}$ sedangkan kehilangan panas pipa kondensor ( $\left.\mathrm{q}_{\mathrm{p}}\right)$ maksimal pada 
kecepatan udara $1.0 \mathrm{~m} / \mathrm{s}$. Semakin besar kecepatan udara untuk $(\mathrm{V})<0.9$ kehilangan panas pipa kondensor $\left(\mathrm{q}_{\mathrm{p}}\right)$ meningkat dengan gradian kenaikan besar, tetapi kecepatan udara untuk (V) $>0.9$ kehilangan panas pipa kondensor $\left(\mathrm{q}_{\mathrm{p}}\right)$ meningkat pula dengan gradien kenaikan yang kecil.

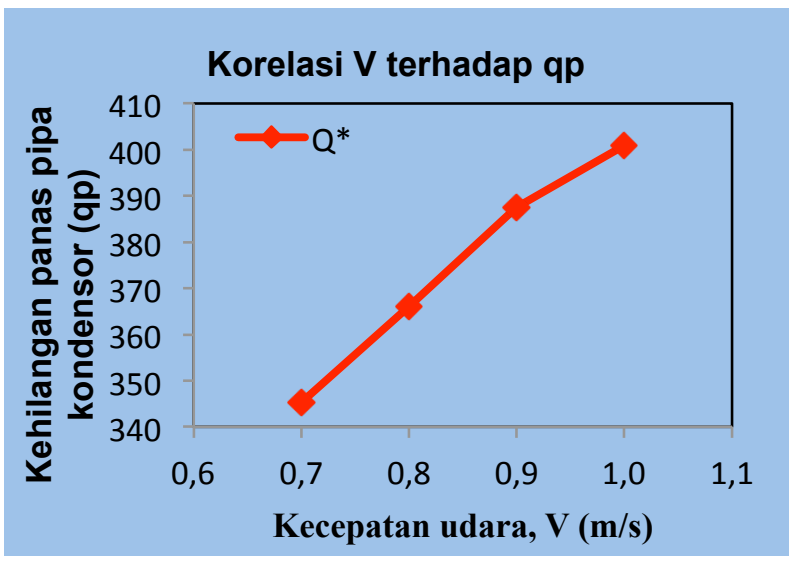

Gambar 7. Korelasi kecepatan udara (V) terhadap kehilangan panas pipa kondensor $\left(q_{p}\right)$

\section{- Kehilangan Panas Steam $\left(q_{s}\right)$}

Hasil eksperimen dengan memvariasikan kecepatan udara $(\mathrm{V})=0,7-1,0 \mathrm{~m} / \mathrm{s}$ pada masukan panas $\left(\mathrm{Q}^{*}\right)=5.400 \mathrm{~kJ} / \mathrm{jam}$ konstan, memperlihatkan bahwa semakin besar kecepatan udara $(\mathrm{V})$, maka kehilangan panas steam $\left(\mathrm{q}_{\mathrm{s}}\right)$ semakin meningkat disajikan pada gambar 8 .

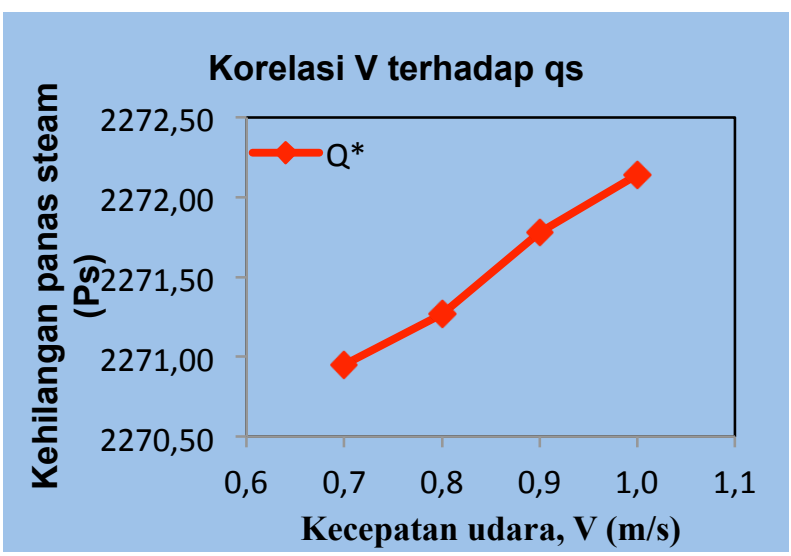

Gambar 8. Korelasi kecepatan udara (V) terhadap kehilangan panas steam $\left(\mathrm{q}_{\mathrm{s}}\right)$

Gambar 8 memperlihatkan bahwa kehilangan panas panas steam $\left(\mathrm{q}_{\mathrm{s}}\right)$ minimal terhadap pada kecepatan udara $0.7 \mathrm{~m} / \mathrm{s}$ sedangkan kehilangan panas panas steam $\left(\mathrm{q}_{\mathrm{s}}\right)$ maksimal pada kecepatan udara $1.0 \mathrm{~m} / \mathrm{s}$. Semakin besar kecepatan udara untuk $(\mathrm{V})<0.9$ kehilangan panas panas steam $\left(\mathrm{q}_{\mathrm{s}}\right)$ meningkat dengan gradian kenaikan besar, tetapi kecepatan udara untuk $\quad(\mathrm{V})>0.9$ kehilangan panas steam $\left(\mathrm{q}_{\mathrm{s}}\right)$ meningkat pula dengan gradien kenaikan yang kecil.

\section{- Laju Kondensasi (qc)}

Hasil eksperimen dengan memvariasikan kecepatan udara $(\mathrm{V})=0,7-1,0 \mathrm{~m} / \mathrm{s}$ pada masukan panas $\left(\mathrm{Q}^{*}\right)=5.400 \mathrm{~kJ} / \mathrm{jam}$ konstan, memperlihatkan bahwa semakin besar kecepatan udara $(\mathrm{V})$, maka laju kondensasi $\left(\mathrm{q}_{\mathrm{c}}\right)$ semakin meningkat disajikan pada gambar 9 .

Gambar 9 memperlihatkan bahwa laju kondensasi $\left(\mathrm{q}_{\mathrm{c}}\right)$ minimal terhadap pada kecepatan udara $0.7 \mathrm{~m} / \mathrm{s}$ sedangkan laju kondensasi $\left(\mathrm{q}_{\mathrm{c}}\right)$ maksimal pada kecepatan udara $1.0 \mathrm{~m} / \mathrm{s}$. Semakin besar kecepatan udara untuk $(\mathrm{V})<0.9$ laju kondensasi $\left(\mathrm{q}_{\mathrm{c}}\right)$ meningkat dengan gradian kenaikan besar, tetapi kecepatan udara untuk (V) $>0.9$ laju kondensasi $\left(\mathrm{q}_{\mathrm{c}}\right)$ meningkat pula dengan gradien kenaikan yang kecil.

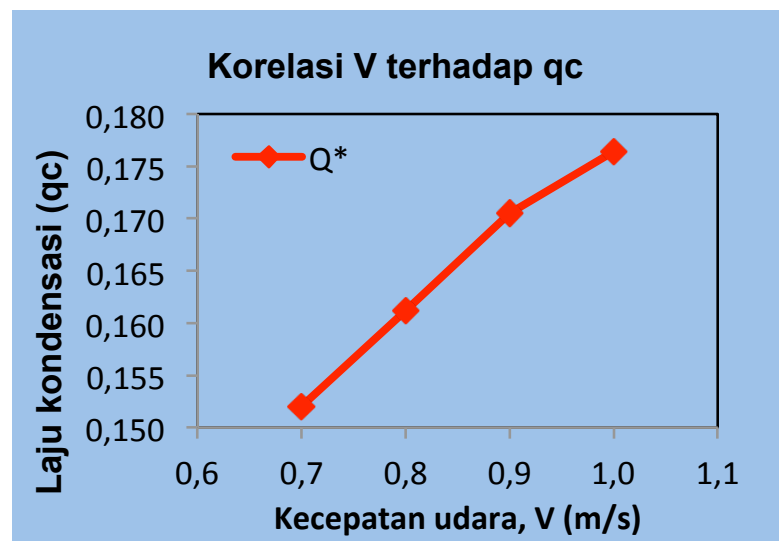

Gambar 9. Korelasi kecepatan udara (V) terhadap laju kondensasi $\left(q_{c}\right)$

\section{KESIMPULAN}

Penelitian laju kondensasi akibat pengaruh kecepatan udara terhadap karakteristik perpindahan panas pada oven pengering pati sagu kapasitas $5 \mathrm{~kg}$, maka dapat disimpulkan sebagai berikut:

1. Semakin besar kecepatan udara untuk (V) $<0,9 \mathrm{~m} / \mathrm{s}$, maka karakteristik perpindahan panas konveksi yakni bilangan Prandt $(\mathrm{Pr})$, bilangan Reynold (Re), bilangan Nusselt $(\mathrm{Nu})$, koefisien konveksi (h), dan laju perpindahan panas konveksi $\left(\mathrm{q}_{\mathrm{k}}\right)$ semakin meningkat dengan gradient kenaikan besar. Sebaliknya untuk $(\mathrm{V})>0,9 \mathrm{~m} / \mathrm{s}$ karakteristik 
perpindahan panas konveksi meningkat pula namun dengan gradient kenaikan kecil. Untuk bilangan $\mathrm{Pr}$ meningkat dari 0.6969 hingga 0.6974 atau meningkat sebesar $0.08 \%$, untuk bilangan $\mathrm{Re}$ meningkat dari 233667,092 hingga 34216,608 atau meningkat sebesar $6,83 \%$, untuk bilangan $\mathrm{Nu}$ meningkat dari 762,576 hingga 1084,454 atau meningkat sebesar $29.68 \%$, untuk $\mathrm{h}$ meningkat dari $102,718 \mathrm{~kJ} / \mathrm{jam} . \mathrm{m}^{2} . \mathrm{K}$ hingga 124,642 $\mathrm{kJ} /$ jam... ${ }^{2} . \mathrm{K}$ atau meningkat sebesar $17.16 \%$ dan $\mathrm{q}_{\mathrm{k}}$ meningkat dari $12542,551 \mathrm{~kJ} / \mathrm{jam}$ hingga $15395,773 \mathrm{~kJ} / \mathrm{jam}$ atau meningkat sebesar $18.53 \%$.

2. Semakin besar kecepatan udara untuk (V) < 0,9 m/s, maka laju kondensasi meningkat dengan gradient kenaikan besar, sebaliknya untuk kecepatan udara $(\mathrm{V})>0,9$ $\mathrm{m} / \mathrm{s}$ laju kondensasi juga meningkat dengan gradient kenaikan kecil. Laju kondensasi meningkat dari $0,152(\mathrm{~kg} / \mathrm{hr}-\mathrm{m})$ hingga 0,171 $(\mathrm{kg} / \mathrm{hr}-\mathrm{m})$ atau meningkat $11.11 \%$.

\section{DAFTAR PUSTAKA}

Anonim, 2004, Penelitian dan Pengembangan Teknologi Pengolahan Sagu sebagai Pangan Pokok di Kawasan Timur Indonesia. Balai Besar Penelitian dan Pengembangan Pasca Panen Pertanian. Badan Litbang Pertanian, Deptan.

Bergman. Th. L, Lavine. A. S, Incropera. F.P, De Witt. D, 2011., "Fundamental of Heat and Mass Transfer", $7^{\text {th }}$ Edition, John Wiley \&Sons, New York.

BPS. 2008, SNI 01-3729-1995

Cengel, Yunus, A., 1998, "Heat Transfer a Practical Approach", McGraw-Hill, New York

Farel, H. N., Putra., M. T, 2012, "Perancangan dan Pengujian Alat Pengering Kakao Dengan Tipe Kabinet Untuk Kapasitas 7,5 kg per Siklus". Jurnal Dinamis, Volume II, No. 10.

Kays, W. M dan Crawford, M. E., 1993, "Convective Heat and Mass Transfer", McGraw-Hill, Inc, New York.

Naylor, D dan Oosthuzen, P. H., 1999, "Introduction to Covective Heat Transfer Analysis", McGraw-Hill, New York.
Purwani, E.Y., Widaningrum, R. Thahir, 2006. "Effect of Moisture of Sago Strach on its Noodle Quality". Indonesia Journal of Agriculture Science 7(1);8-14.

Rindengan, B. dan S. Karauw. 2003. Potensi Pati Sagu sebagai Bahan Baku Plastik, Dalam Sagu untuk Ketahanan Pangan. Prosiding Seminar Nasional Sagu. Pusat Penilitian dan Pengembangan Perkebunan. Manado, 6 Oktober 2003

Wang S. C., Yang Y. T and Chen, C. K, 2003., "Effect of Uniform Suction on Laminar Film wise Condensation on a finite-size Horizontal Flat Surface ini a Porous Medium", Int. Journal of Heat and Mass Transfer, Vol. 46, 4003-4011

Wark, K. Jr, Richard, D. E, 1999., "Termodinamics", $6^{\text {th }}$ Edition, McGrawHill International Editions, New York.

Widaningrum, Endang Yuli Purwani dan S. Joni Munarso. 2005. Kajian Terhadap SNI Mutu Pati Sagu, Jurnal Standardisasi Vol. 7 (3), p91-98.

Widyawan. A dan Fachlevie. F, 2013, Studi Pemanfaatan Condensate Outlet Steam Trap sebagai air Umpan Balik di Pabrik Amoniak PUSRI-IB, Jurnal Rekayasa Proses, Volume 7, (1), 2013. 